\title{
OPTICALLY ACTIVE GOSSYPOL AS A CIRCULAR DICHROISM PROBE OF INTERACTIONS WITH SERUM ALBUMINS
}

\author{
KEVIN J. WHALEY, D.S. SAMPATH and P. BALARAM * \\ Molecular Biophysics Unit, Indian Institute of Science, Bangalore 560012 (India)
}

(Received May 8th, 1984)

Key words: Gossypol; $C D$; Albumin interaction; Fluorescence quenching

The (+)-enantiomer of the polyphenolic binaphthyl gossypol, has been shown to be a useful CD probe of interactions with human and bovine serum albumin. (+)-Gossypol binds to albumin with the same affinity as racemic ( \pm )-gossypol, as shown by fluorescence quenching, and also displaces bilirubin from its albumin binding site. The $\mathrm{CD}$ characteristics of bound gossypol are different in the case of the two proteins.

\section{Introduction}

The polyphenolic, binaphthyl derivative, gossypol (Scheme I), isolated from cottonseed oil [1], has been shown to possess antifertility activity [2]. More recently, gossypol has been reported to be effective against herpes virus [3] and in treatment of malaria [4] and Chagas' disease [5]. These remarkable properties of gossypol have stimulated interest in its interactions with proteins [6,7] and have led to the suggestion that its antifertility effects may be a consequence of its ability to specifically inhibit the sperm enzyme, lactate dehydrogenase $X[8,9]$. Gossypol has also been shown to interact strongly with serum albumins and

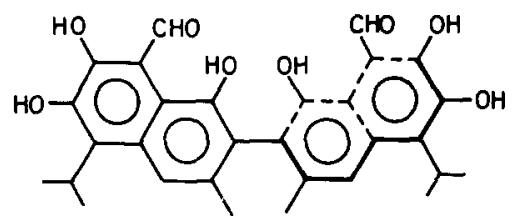

Scheme I. Structure of gossypol.

\footnotetext{
* To whom correspondence should be addressed.
}

glutathione $S$-transferase, binding competitively at the bilirubin binding site on these proteins $[6,7]$. All these binding studies have been carried out with racemic ( \pm -gossypol. By virtue of the extremely restricted rotation about the central $\mathrm{C}-\mathrm{C}$ bond in binaphthyls, gossypol can display atropisomerism and exist in optically active enantiomeric forms. Early investigations have established that $(+)$-gossypol can be isolated from the bark of the tree Thespesia populnea $[10,11]$. We describe in this report the CD spectrum of $(+)$ gossypol, demonstrate that its interaction with serum albumins is similar to that observed for ( \pm )-gossypol and establish its potential utility as a probe of gossypol binding sites on proteins.

\section{Materials and Methods}

( \pm )-Gossypol, bilirubin and serum albumins were obtained from Sigma. (+)-Gossypol was isolated from the bark of the tree $T$. populnea as described earlier [10] and recrystallized from acetone $/ \mathrm{H}_{2} \mathrm{O}$. Both $(+)$ - and ( \pm -gossypol were analyzed for purity by HPLC [12] on a reversephase RP-18 Lichrosorb column using an LKB HPLC system (Solvent 80\% methanol/water/0.1\% 
$\mathrm{H}_{3} \mathrm{PO}_{4}$, flow rate $1 \mathrm{ml} / \mathrm{min}$, retention time 32.5 $\min$ ).

Stock solutions of $(+)$ - or $( \pm)$-gossypol were prepared freshly in ethanol or methanol for the spectroscopic experiments. Fluorescence spectra were recorded on Perkin-Elmer MPF-44A or Hitachi Model 650-60 spectrometers. CD spectra were recorded on a JASCO J 20 spectropolarimeter.

\section{Results and Discussion}

The emission spectrum of human serum albumin was excited at $275 \mathrm{~nm}$. The protein has a lone tryptophan residue at position 214 [13]. The observed spectrum represents both tyrosine and tryptophan contributions. Addition of $(+)$-gossypol results in clear quenching of protein fluorescencce. The inset in Fig. 1 demonstrates that $(+)$ - and ( \pm )-gossypol quench human serum albumin fluorescence in almost identical fashion,

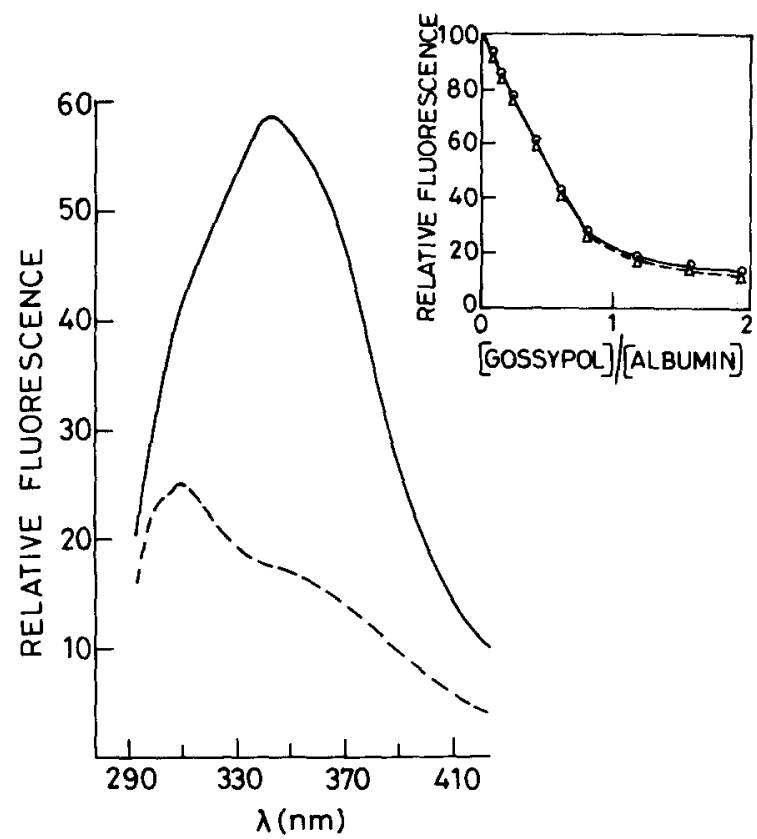

Fig. 1. Fluorescence spectra of human serum albumin, $0.5 \cdot 10^{-6}$ $\mathrm{M}$ in $0.02 \mathrm{M} \mathrm{KH} \mathrm{PO}_{4}-\mathrm{K}_{2} \mathrm{HPO}_{4}$ buffer (pH 7.4) (- .....- after addition of $6.6 \cdot 10^{-7} \mathrm{M}(+)$-gossypol. $\lambda_{\mathrm{ex}}=275$ $\mathrm{nm}$. (inset) Quenching of human serum albumin fluorescence at $\lambda=320 \mathrm{~nm}\left(\lambda_{\mathrm{ex}}=280 \mathrm{~nm}\right)$ on addition of $(+)$-gossypol $(O)$ and $( \pm)$-gossypol $(\Delta)$, in $0.02 \mathrm{M}$ potassium phosphate buffer $/ 0.1 \mathrm{M} \mathrm{NaCl}$ (pH 7.4). suggesting that both enantiomeric forms of gossypol bind equally well to the protein. A $K_{\mathrm{d}}$ value of $5 \cdot 10^{-7} \mathrm{M}$ can be estimated for (+)- and $( \pm$ )-gossypol binding to human serum albumin. A $K_{\mathrm{d}}$ of $0.9 \cdot 10^{-7} \mathrm{M}$ has been estimated earlier, based on a bilirubin displacement method [6]. Fig. 1 shows clearly that gossypol preferentially quenches tryptophan fluorescence in human serum albumin $\left(\lambda_{\mathrm{em}}=343 \mathrm{~nm}\right)$, as compared to tyrosine fluorescence $\left(\lambda_{\mathrm{em}}=306 \mathrm{~nm}\right)$. A similar effect has been reported earlier for the binding of bilirubin to serum albumins [14].

The effect of addition of (+)-gossypol on the $C D$ spectra of bilirubin bound to human serum albumin is shown in Fig. 2. Displacement of bilirubin from the protein is accompanied by a diminution of the positive band at $450 \mathrm{~nm}$ and the negative band at approx. $395 \mathrm{~nm}$, while the intensities of the (+)-gossypol bands, at $388 \mathrm{~nm}$ (positive) and $337 \mathrm{~nm}$ (negative), increase. These observations further confirm that $(+)$-gossypol binds to human serum albumin and displaces bilirubin in a manner analogous to that reported for $( \pm)$ gossypol [6].

Fig. 3 shows the $C D$ spectrum of ( + -gossypol at $\mathrm{pH}$ 7.4. Intense bands at 385 and $283 \mathrm{~nm}$ (positive), $231 \mathrm{~nm}$ (negative) and weaker bands at 260, 313 and $338 \mathrm{~nm}$ (negative) and $246 \mathrm{~nm}$ (positive) are observed. In the presence of human and

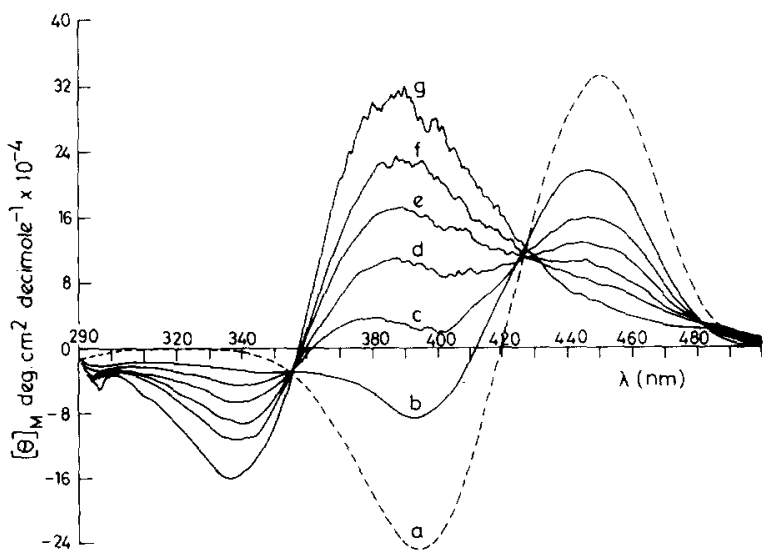

Fig. 2. Effect of addition of (+)-gossypol on the CD spectrum of bilirubin $\left(50 \cdot 10^{-6} \mathrm{M}\right)$ bound to human serum albumin $\left(50 \cdot 10^{-6} \mathrm{M}\right)$ in potassium phosphate buffer $/ 0.1 \mathrm{M} \mathrm{NaCl}(\mathrm{pH}$ 7.4). (a) no gossypol; (b) $50 \mu \mathrm{M}$ (+)-gossypol; (c) $100 \mu \mathrm{M}$; (d) $150 \mu \mathrm{M}$; (e) $200 \mu \mathrm{M}$; (f) $250 \mu \mathrm{M}$; (g) $350 \mu \mathrm{M}$. 


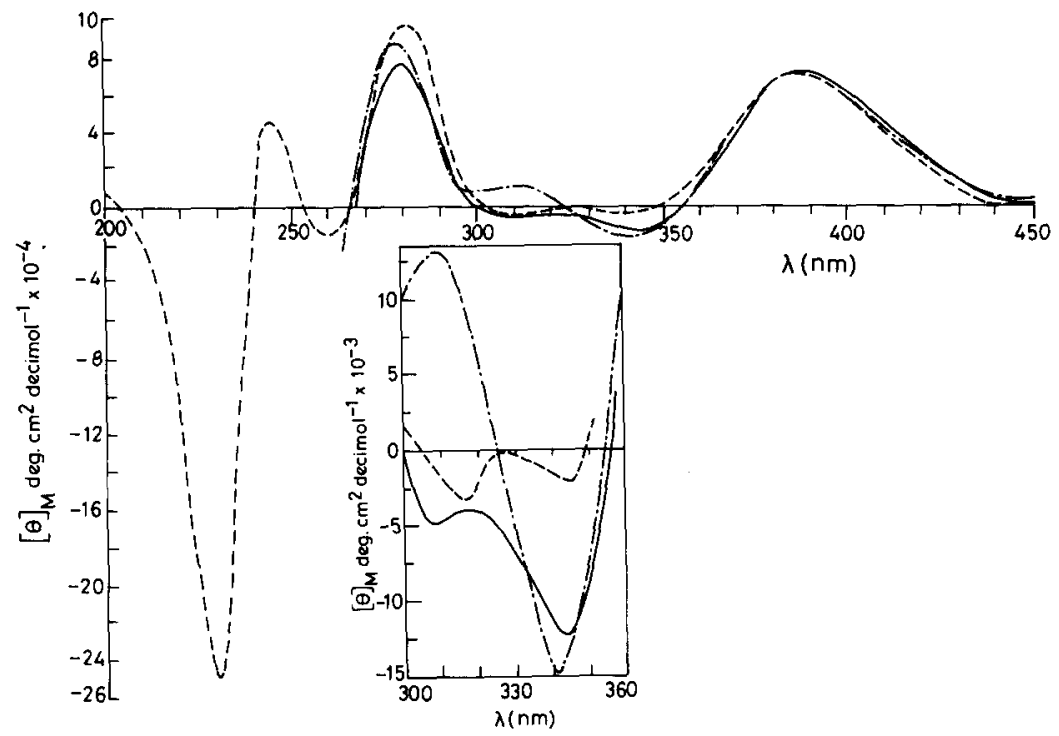

Fig. 3. Effect of serum albumins on the CD spectrum of $(+)$-gossypol. -.... -, $50 \mu \mathrm{M}(+)$-gossypol; $\longrightarrow, 50 \mu \mathrm{M}(+)$-gossypol +50 $\mu \mathrm{M}$ human serum albumin; -.·- $\cdot$, 50 $\mu \mathrm{M}(+)$-gossypol $+50 \mu \mathrm{M}$ bovine serum albumin. Solutions were in unbuffered were in unbuffered water adjusted to $\mathrm{pH} 6.8$.

bovine serum albumin, distinct reproducible changes are observed in the CD spectrum of $(+)$ gossypol. The $\mathrm{CD}$ parameters for (+)-gossypol under different conditions are summarized in Table I. Fig. 3 (inset) illustrates the significant changes in the CD spectra in the region $300-360$ $\mathrm{nm}$, which occur on binding to albumins. The spectra observed on interaction with human and bovine serum albumin differ, suggesting that the bound conformation of (+)-gossypol may be different in the two cases. This, in turn, may be a consequence of differences in the nature of the protein binding sites.

The above results suggest that (+)-gossypol can be used as a $C D$ probe of interactions with proteins. In the case of serum albumins, it appears that the gossypol binding site is not capable of significant chiral discrimination and accommodates both enantiomeric forms. It has been reported that oral administration of ( \pm )-gossypol to male hamster results in impairment of fertility, whereas no such effect is observed for (+)-gossypol [15]. However, recent studies suggest that both $(+)$ and $( \pm)$-gossypol are equally effective in inhibition of proacrosin conversion to acrosin and in inhibition of oocyte penetration by human spermatozoa [16]. These observations provide a further example of gossypol interaction with pro-

TABLE I

\section{PARAMETERS OF (+)-GOSSYPOL}

Ellipticities are expressed as $[\theta] \mathrm{deg} \cdot \mathrm{cm}^{2} \cdot \mathrm{decimol}^{-1}$. Spectra were recorded as described for Fig. 3. Other bands of gossypol (pH 7.0) are observed at $283 \mathrm{~nm}(+90000), 260 \mathrm{~nm}(-10000), 246 \mathrm{~nm}(+35000)$ and $231 \mathrm{~nm}(-202000)$ (values in parentheses are molar ellipticities). HSA, human serum albumin; BSA, bovine serum albumin.

\begin{tabular}{|c|c|c|c|c|c|c|c|}
\hline & & $\lambda(\mathrm{nm})$ & {$[\theta]$} & $\lambda(\mathrm{nm})$ & {$[\theta]$} & $\lambda(\mathrm{nm})$ & {$[\theta]$} \\
\hline \multirow[t]{3}{*}{ Gossypol } & pH 3.7 & 310 & -3600 & 341 & -5600 & 385 & +70000 \\
\hline & pH 7.0 & 312 & -2300 & 339 & -1100 & 385 & +66000 \\
\hline & pH 9.9 & 313 & -2800 & 341 & -4000 & 385 & +57000 \\
\hline \multirow[t]{3}{*}{ Gossypol + HSA } & pH 3.7 & 310 & -5000 & 340 & -36000 & 388 & +66000 \\
\hline & $\mathrm{pH} 6.8$ & 308 & -5500 & 343 & -12000 & 888 & +70000 \\
\hline & pH 9.9 & 297 & -13000 & 337 & -27000 & 385 & +57000 \\
\hline \multirow[t]{2}{*}{ Gossypol + BSA } & pH 7.0 & 310 & +4200 & 343 & -18000 & 385 & +66000 \\
\hline & pH 9.9 & 305 & +3400 & 340 & -19500 & 385 & +50000 \\
\hline
\end{tabular}


teins and cells, where a differentiation between the enantiomers is not achieved. The use of (+)-gossypol as a $C D$ probe should be valuable in defining the conditions under which specific chiral recognition can be achieved. This, in turn, may provide a basis for understanding the molecular interactions involved in the differential effects of $(+)$ - and ( \pm$)$-gossypol on male fertility.

\section{Acknowledgements}

KJW thanks the UNESCO-UNDP for award of a fellowship. This research was supported by the Department of Science and Technology, Government of India.

\section{References}

1 Abou-Donia, M.B. (1976) Residue Rev. 61, 125-160

2 Prasad, M.R.N. and Diczfalusy, E. (1982) Int. J. Androl., Suppl. 5, 53-70

3 Wichmann, K., Vaheri, A. and Luukkainen, T. (1982) Am. J. Obstet. Gynecol. 142, 593-594.
4 Vander Jagt, D.L., Heidrich, J.E., Royer, R.E. and Hunsaker, L.A. (1982) Fed. Proc. 41, 6769.

5 Montamat, E.E., Burgos, C., Gerez de Burgos, N.M., Rovai, L., Blanco, A. and Segura, E.L. (1982) Science 218, 288-289

6 Royer, R.E. and Vander Jagt, D.L. (1983) FEBS Lett. 157, 28-30

7 Vander Jagt, D.L., Dean, V.L., Wilson, S.P. and Royer, R.E. (1983) J. Biol. Chem. 258, 5689-5694

8 Lee, C.Y. and Malling, H.V. (1981) Fed. Proc. 40, 718

9 Olgiati, K.L. and Toscano, W.A.Jr., (1983) Biochem. Biophys. Res. Commun. 115, 180-185

10 King, T.J. and de Silva, L.B. (1968) Tetrahedron Lett. 261-263

11 Datta, S.C., Murti, V.V.S. and Seshadri, T.R. (1968) Curr. Sci. 37, 135

12 Abou-Donia, S.A., Lasker, J.M. and Abou-Donia, M.B. (1981) J. Chromatogr. 206, 606-610

13 Brown, J.R. (1975) Fed. Proc. 34, 591

14 Mathew, M.K. and Balaram, P. (1980) FEBS Lett. 115, 91-94

15 Waller, D.P., Fong, H.H.S., Cordell, G.A. and Soejarto, D.D. (1981) Contraception 23, 653-660

16 Kennedy, W.P., Van der Ven, H.H., Straus, J.W., Bhattacharyya, A.K., Waller, D.P., Zaneveld, L.J.D. and Polakoski, K.L. (1983) Biol. Reprod. 29, 999-1009. 